\title{
The effect of low-level red and near- infrared photobiomodulation on pain and function in tendinopathy: a systematic review and meta-analysis of randomized control trials
}

\author{
Nicholas Tripodi ${ }^{1,2,3^{*}}$ (D) Jack Feehan ${ }^{1,3,4}$ (D) Maja Husaric ${ }^{1,2}$ (D) Fotios Sidiroglou ${ }^{2,5}$ (D) and Vasso Apostolopoulos ${ }^{1}$ (i)
}

\begin{abstract}
Background: Tendinopathy is a common clinical condition that can significantly affect a person's physical function and quality of life. Despite exercise therapy being the mainstay of tendinopathy management, there are many potential adjunct therapies that remain under investigated, one of which is photobiomodulation (PBM). PBM uses varied wavelengths of light to create a biological effect. While PBM is used frequently in the management of tendinopathy, high quality evidence supporting its utility is lacking.

Methods: A systematic search of the Pubmed, CINAHL, SCOPUS, Cochrane Database, Web of Science and SPORTSDICUS databases was performed for eligible articles in August 2020. Randomized Control Trials that used red or near-infrared PBM to treat tendinopathy disorders that made comparisons with a sham or 'other' intervention were included. Pain and function data were extracted from the included studies. The data were synthesized using a random effects model. The meta-analysis was performed using the mean difference (MD) and standardized mean difference (SMD) statistics.

Results: A total of 17 trials were included $(n=835)$. When compared solely to other interventions PBM resulted in similar decreases in pain (MD $-0.09 ; 95 \% \mathrm{Cl}-0.79$ to 0.61 ) and a smaller improvement in function (SMD $-0.52 ; 95 \%$ $\mathrm{Cl}-0.81$ to -0.23$)$. When PBM plus exercise was compared to sham treatment plus exercise, PBM demonstrated greater decreases in pain (MD 1.06; 95\% Cl 0.57 to 1.55) and improved function (MD 5.65; 95\% Cl 0.25 to 11.04). When PBM plus exercise was compared to other interventions plus exercise, no differences were noted in pain levels (MD 0.31; $95 \% \mathrm{Cl}-0.07$ to 0.70 ). Most studies were judged as low-risk of bias. The outcome measures were classified as very low to moderate evidence quality according to the Grading of Recommendation, Development and Evaluation tool.
\end{abstract}

Conclusion: There is very-low-to-moderate quality evidence demonstrating that PBM has utility as a standalone and/or adjunctive therapy for tendinopathy disorders.

\footnotetext{
* Correspondence: nicholas.Tripodi@vu.edu.au

${ }^{1}$ Institute for Health and Sport, Victoria University, Room 1.16, 301 Flinders

Lane, Melbourne, VIC 3000, Australia

${ }^{2}$ First Year College, Victoria University, Melbourne, Australia

Full list of author information is available at the end of the article
}

C C The Author(s). 2021 Open Access This article is licensed under a Creative Commons Attribution 4.0 International License, which permits use, sharing, adaptation, distribution and reproduction in any medium or format, as long as you give appropriate credit to the original author(s) and the source, provide a link to the Creative Commons licence, and indicate if changes were made. The images or other third party material in this article are included in the article's Creative Commons licence, unless indicated otherwise in a credit line to the material. If material is not included in the article's Creative Commons licence and your intended use is not permitted by statutory regulation or exceeds the permitted use, you will need to obtain permission directly from the copyright holder. To view a copy of this licence, visit http://creativecommons.org/licenses/by/4.0/ The Creative Commons Public Domain Dedication waiver (http://creativecommons.org/publicdomain/zero/1.0/) applies to the data made available in this article, unless otherwise stated in a credit line to the data. 
Trial registration: PROPERO registration number: CRD42020202508.

Keywords: Tendinopathy, Photobiomodulation, Pain, Low-level laser therapy, Meta-analysis, Systematic review

\section{Background}

Tendinopathies represent a common presentation to clinical practice, particularly in active persons [1]. For instance, Achilles tendinopathy has been reported to occur at a rate of 2.35 per 1000 patients [2], whilst occurring between $6.2-9.5 \%$ in athletic populations [3]. Regardless of cohort, tendinopathy can profoundly affect a person's quality of life and ability to perform activities of daily living, and cause considerable economic impact [4]. Traditionally, tendon pain was known as tendinitis, referring to the pain and inflammation thought to be associated with this condition [4]. However, as research in this area advanced, it was noted that most painful tendon disorders are chronic disorders, lacking a primary inflammatory driver [5-7]. Hence, the next term that evolved to describe this disorder was tendinosis, referring to the deleterious histopathological changes that can occur within a painful tendon [5]. More contemporary research now advocates for the term tendinopathy when describing any painful tendon disorder $[7,8]$. Despite the original definition being grounded in the histopathological and clinical findings [7], tendinopathy is now defined as persistent tendon pain and loss of function related to mechanical loading [8], which may be associated with radiological changes [9].

Despite extensive research efforts in recent years, the complete pathophysiological picture of tendinopathy remains poorly understood [1]. However, it is known that four key cellular changes typify tendon pathology: 1 . Increased number and metabolism of tenocytes; 2 . Large proteoglycan presence, causing increased water content; 3 . Abnormal collagen alignment and 4. New blood vessel and nerve growth within the tendon [10]. Regardless of the exact pathophysiological mechanisms, diagnosis of tendinopathy is primarily clinical, rather than radiological [1]. Tendinopathy presents as localized tendon pain that is correlated to mechanical load, that is beyond the tendon's current capacity [8]. A clinician must pay close attention to changes in activity load and other rheumatological, metabolic and endocrine risk factors, with pain being produced during specific provocative movements, or by activities of daily living [1]. Furthermore, given the poor correlation between pain, function and histopathological radiological findings [10], and the absence of a defined nociceptive tendinopathic pathway [1], it is also important to consider the psychosocial influences of tendinopathy $[1,4,11]$.

Due to the common prevalence of tendinopathy there is a large variety of treatment methodologies that have been employed, of which, exercise rehabilitation is the most well supported $[1,12,13]$. There are also a number of adjunct therapies used in the management of tendinopathy, including: Extracorporeal shock wave therapy (ESWT), Non-steroidal anti-inflammatory drugs (NSAI Ds), injection therapies such as platelet rich plasma (PRP), corticosteroids (CS), and prolotherapy, transdermal application of CS through the method of Iontophoresis, and also passive interventions such as stretching and deep friction massage $[1,13]$. While some of these treatments show promise, most have been shown to be no better, or worse that exercise rehabilitation [1].

An emerging and underexplored treatment in the management of tendinopathy is photobiomodulation (PBM) [14]. While the exact physiological mechanisms underpinning PBM are yet to be fully described, the prevailing theory is based on the interplay between adenosine triphosphate (ATP), nitric oxide (NO) and cytochrome c oxidase (complex IV of the mitochondria) [15]. It is thought that both red and near-infrared (NIR) light have a high affinity for CCO [15]. During routine metabolism, or in instances of cellular stress, NO may competitively bind to $\mathrm{CCO}$, displacing oxygen, slowing or limiting ATP production. PBM has been suggested to displace the $\mathrm{NO}$ from $\mathrm{CCO}$, allowing oxygen to more freely interact with CCO, thus enhancing ATP production [15]. Despite this mechanism being widely accepted, there is no evidence to date that shows a direct photobiological interaction with $\mathrm{CCO}[14,16]$. Additionally, there are many other secondary mechanisms by which PBM may exert its effects. These include an increased production of reactive oxygen species (ROS), which can lead to upregulations in gene transcription and downstream protein expression [14, 17], and additionally may modulate key immune cells leading to improved tissue healing and neural fibre inhibition $[14,18,19]$.

At a more fundamental level, how PBM affects tendon tissue in vitro, and in animal models has been investigated. In vitro PBM appears to influence multiple mechanisms related to growth and proliferation. Specifically, $\mathrm{PBM}$ can increase the expression of genes related to proliferating cell nuclear antigen (PCNA) and transforming growth factor- $\beta 1$ (TGF- $\beta 1$ ) $[20,21]$; Cyclins E, A, and B1 [21]; expression of genes related to type I collagen, decorin [22] and dynamin II [23], all of which are key regulators of the healing response. Interestingly, PBM has also been shown to decrease the expression of genes related to inflammation such as TNF- $\alpha$ [24] and IL-6 in 
tenocytes [25]. The positive effects of PBM have also been observed in animal models of tendinopathy, showing mild improvements in functional healing compared to non-irradiated controls [26]. However, as with many areas of study within the field of PBM, a recent review article reported that the lack of a standardized process for treating animal tendons with PBM makes comparison difficult, and its further development and standardization should be given priority [27].

The impact of PBM on tendinopathy has been appraised with reviews on specific tendinopathies such as: lateral elbow tendinopathy [28]; Achilles tendinopathy [29]; and shoulder tendinopathy [30]; all of which demonstrated mixed effects, possibly due to a lack of consistent PBM application variables between studies. There has also been a systematic review and meta-analysis of the effects of PBM on all human tendinopathies, however it was reported in 2010, and included both randomized controlled trials (RCTs) and controlled clinical trials (CCTs) [31], and again mixed results were reported. Building on these previous works, and given the proposed universal effects of PBM, the aim of this work was to synthesize the current evidence describing the impact of low-intensity red and NIR PBM on pain and function in all tendinopathy disorders in human patients. Specifically, appraising only RCTs, we analyzed the effects of $\mathrm{PBM}$ on tendinopathy in three domains: Pain, PROMS and Strength.

\section{Methods}

\section{Protocol and registration}

This review was prospectively registered in the PROSPERO database (registration number: CRD42020202508). It was also completed and structured according to the Preferred Reporting Items for Systematic Reviews and Meta-Analyses (PRISMA) guidelines [32].

\section{Eligibility criteria}

Studies included in this review were any randomized controlled trials that used up to a class $3 \mathrm{~B}$ power laser, or equivalent light sources within the $600 \mathrm{~nm}-1100 \mathrm{~nm}$ spectrum, to treat any diagnosed tendinopathy or tendinopathy-related disorders. Given the proposed universal effects of PBM, and the wide-ranging appraisal aim of this review, all tendinopathy and tendinopathyrelated disorders were pooled. Comparisons had to be made to placebo or other clinical interventions in human adults. Further, the trials needed to report Visual Analogue Scale (VAS), validated Patient Reported Outcome Measure (PROM) data and/or changes in muscle strength. Studies were excluded if they were produced before the year 2000 given the change in both the diagnosis and understanding of tendinopathy [7] and the changes in PBM application [33] in that time. Articles unavailable in English were excluded.

\section{Information sources and search strategy}

The search terms used in this review were: (Photobiomodulation OR Low-level laser OR LLLT) AND (tendon* OR tendin* OR epicond* OR teno* OR elbow OR bursitis OR subacromial). The databases that were searched were: Pubmed, CINAHL, SCOPUS, Cochrane Database, Web of Science, SPORTSDiscus. This search was completed by 1st August, 2020. An updated search was performed in April 2021 and yielded no additional results. Reference lists of relevant PBM reviews were also searched. A detailed description of the search can be found in Table 1 of Additional file 1.

\section{Study selection}

The titles and abstract of all the studies yielded in the initial search were screened by two of the authors (NT and JF) for eligibility using the Covidence (Melbourne, Australia) platform. Any disagreements were resolved by a third author $(\mathrm{MH})$. From here, full-text analysis was completed by the two of the authors (NT and JF) and again resolved by a third $(\mathrm{MH})$. The authors of studies which reported insufficient data for the meta-analysis were contacted by email, however, were excluded if no response was given.

\section{Risk of Bias}

Two of the authors (NT and JF) assessed the included studies for bias using the Cochrane Collaboration's riskof-bias tool [34]. Publication bias was assessed by funnel plot analysis generated by Review Manager Version 4.5 (The Cochrane Collaboration, Denmark), where there were more than 10 studies to analyze.

\section{Data collection process}

Data of interest was extracted individually by two of the authors (NT and JF), with any disputes or inconsistencies resolved by the addition of a third author $(\mathrm{MH})$, and then reaching a consensus decision.

\section{Data items}

The primary outcomes taken for this study were pain intensity, in the form of the VAS, validated PROMS and changes in muscle strength. Range of motion measurements were excluded as they are not considered to be a core domain of tendinopathy [35]. The secondary outcome taken was reporting of adverse effects.

\section{Summary measures}

As the primary measurements were all reported as continuous data, VAS and PROM data were combined using the mean difference (MD) statistic, while change in 
muscle strength data was analyzed using the standardized mean difference (SMD) statistic (given the heterogeneity in measuring muscle strength), using the change scores between time points. As only three of the included studies reported the SD change score [36-38], the correlation coefficient was calculated to be 0.8 based on these studies [39]. The data then underwent a sensitivity analysis comparing the meta-analysis results using a correlation coefficient of 0.2 and 0.8 . As no change in the results were detected with either coefficient, the correlation coefficient of 0.8 was used for the final analysis VAS data was reported on a scale of $0-10$, with data reported on a scale of $0-100$ transformed to the $0-10$ scale. PROM data was reported on a scale of $0-100$. Studies that reported multiple VAS sub-scales (i.e. VAS rest, VAS night, etc.) and strength testing measurements means were averaged, and their standard deviation pooled according to previously described measures [39]. Studies that reported a 95\% confidence interval (CI), and not the SD, were converted to SD [39].

\section{Synthesis of results}

Two authors (NT and JF) completed the analysis using both Microsoft Excel (Microsoft, USA) and Review Manager Version 4.5 (The Cochrane Collaboration, Denmark). A random effects meta-analysis was used to analyze the results, with the $\mathrm{I}^{2}$ statistic being used to assess study heterogeneity. The trials were grouped according to VAS, specific PROM and strength measurements. Given the variability in design amongst the included studies, multiple subgroupings were made according to time points analyzed and comparison treatments and controls. 'End of treatment' was defined as end of a 2-4 week course of the treatment intervention, while 'Follow Up' was defined as 3 months posttreatment.

The evidence quality of each outcome was subjectively assessed using the Grading of Recommendation, Development and Evaluation (GRADE) tool [40]. Using the criteria from Tomazoni, Almeida [41], five factors and threshold criteria were used to assess the evidence quality: Risk of Bias: $>25 \%$ of trials classified at high risk of bias; Inconsistency: $\mathrm{I}^{2}>50 \%$; Indirectness: $>50 \%$ of participants not related to trial's target audience; Imprecision: <400 participants in the comparison for continuous outcomes; and Publication Bias: funnel plot if $>10$ trials in same comparison [41]. The evidence quality could be categorized according to four ratings: High; Moderate; Low; and Very Low. Each time an outcome did not meet each of the threshold criteria it was downgraded one level per criteria. For example, if one measure did not meet the thresholds for risk of bias and Inconsistency it was classified as low-quality evidence, downgraded from high-quality evidence.

\section{Results}

\section{Search summary}

The detailed search strategy is shown in Table 1 of Additional file 1 . The initial search strategy yielded 1230 results, after title and abstract screening of these results, 104 studies remained. When these were subjected to full-text screening 22 studies were eligible, of which 17 were included in the meta-analysis [36-38, 42-55] (Fig. 1). The five eligible, but excluded studies, were omitted due to insufficient data, which could not be obtained by contacting the authors [56-60]/ The pooled studies equated to a total of $(n=835)$ participants.

\section{Included study characteristics \\ Participant diagnosis}

Of the included studies, one investigated $(n=1)$ Achilles Tendinopathy (AT) [53]; one investigated De Quervain's Tenosynovitis (DQT) $(n=1)$ [51]; seven $(n=7)$ investigated Lateral Elbow Tendinopathy (LET) [36, 43, 45, 46, $48,50,52]$; one $(n=1)$ investigated Patella Tendinopathy (PT) [38]; and seven $(n=7)$ investigated Sub-acromial Syndrome/Rotator Cuff Tendinopathy (SAS/RT) [37, 42, 44, 47, 49, 54, 55] (Table 1).

\section{Interventions}

There were a wide array of PBM application variables used within the included studies. All the studies used NIR light, ranging from $0.5-5 \mathrm{~J} / \mathrm{cm}^{2}$, and all studies irradiated multiple sites. Additionally, there were a number of studies that did not report all necessary light application variables $[36,42,46,47,49,51,54,55]$ (Tables 1 and 2). Other comparative interventions ("other interventions") included: Phonophoresis and Iontophoresis [43]; ESWT [46]; High-Intensity Laser Therapy (HILT) [48]; Passive Physiotherapy [37]; and US [51]; with the remaining studies using exercise alone $[36,42,50,52$, $53,55]$, or exercise plus another intervention $[45,54]$. Only four studies used the WALT guidelines [33] to inform their treatment protocols $[36,51,53,54]$ (Tables 1 and 2).

\section{Outcome measures}

All the included studies used VAS as an outcome measure. Of the studies that used PROMS in their measures, four $(k=4)$ studies used the Disabilities of the Arm, Shoulder and Hand (DASH) measure [36, 45, 50, 55]; with one $(k=1)$ using the Quick DASH (Q-DASH) [48]; two $(k=2)$ used the Patient Reported Tennis Elbow Evaluation (PRTEE) [36, 43]; two $(n=2)$ used the Shoulder Disability Questionnaire (SDQ) $[37,55]$; three $(k=3)$ used the Shoulder Pain and Disability Index (SPADI) $[44,47,49]$; and one $(k=1)$ study used the Victoria Institute of Sport Assessment-Patella Tendon (VISA-P) [38]. Due to the heterogeneous nature, and limited 


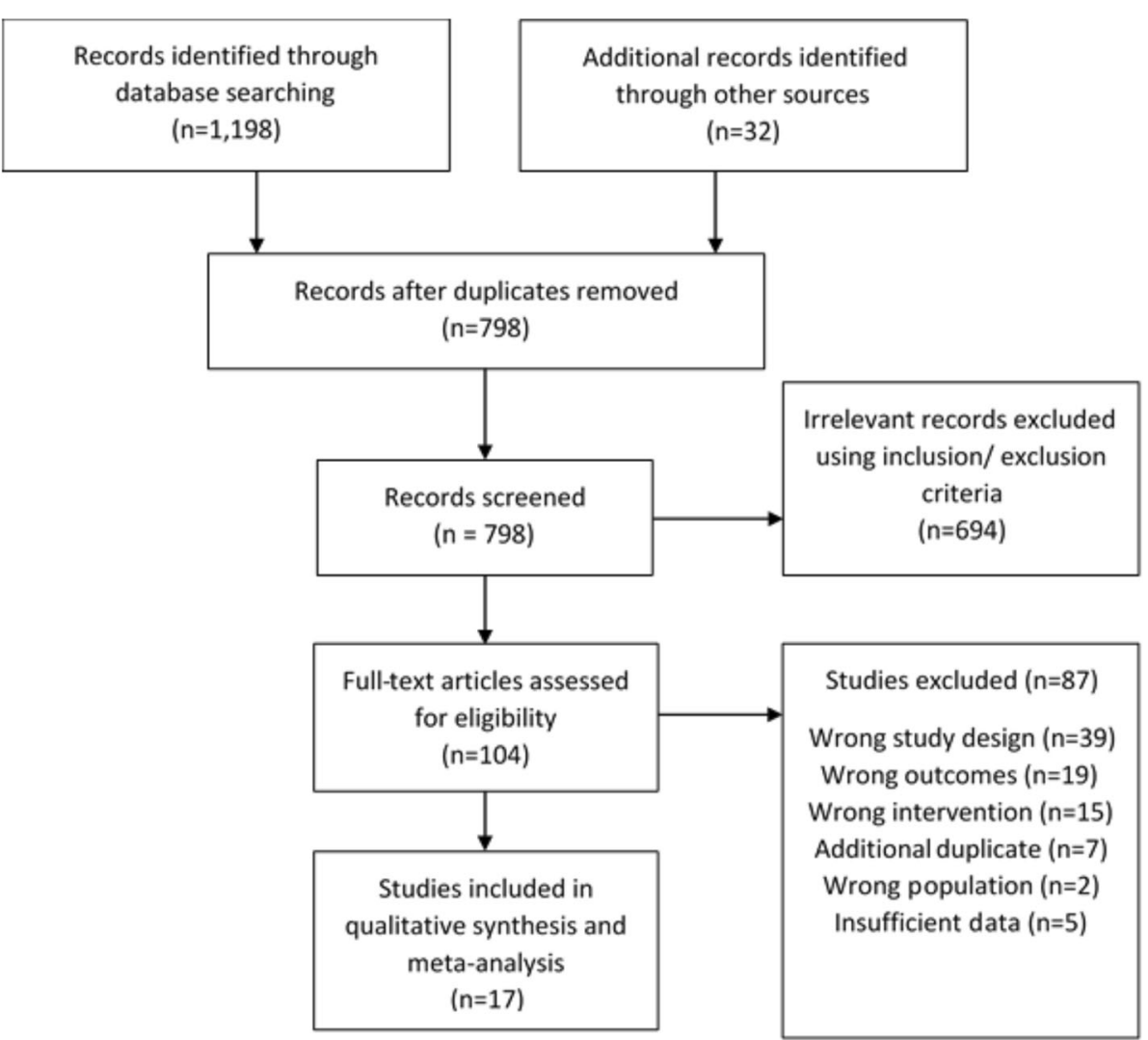

Fig. 1 Literature search process according to the PRISMA guidelines

numbers of study interventions, only the DASH scores could be subject to meta-analysis. Additionally, there were $10(k=10)$ studies that used muscle strength scores and an outcome measure [36, 38, 43, 45, 46, 48, 50-52, 55] (Table 1). Only five studies reported if any adverse effects occurred in the trial, of which there were none $[42,44,47,48,55]$.

\section{Risk of Bias}

When pooled together the included studies were judged to a low risk of bias $68.1 \%$ of the time, an unclear risk of bias $23.5 \%$ of the time, and high risk of bias $8.4 \%$ of the time. Largely, the included studies tended to under report the randomization and blinding protocols, with some studies also failing to report all the required light parameters, hence being judged as being subject to 'other bias' (Fig. 2). Publication bias via funnel plot analysis was not completed as none of the individual forest plots contained $>10$ studies [34].

\section{VAS measures}

\section{PBM only versus other interventions only}

When compared to other interventions only (Phonophoresis, Iontophoresis, ESWT, HILT, CS Injection and US), PBM only, demonstrated similar effects from baseline-end of treatment (MD -0.09; 95\% CI --0.79 to $\left.0.61 ; \mathrm{I}^{2}=78 \% ; n=105\right)$. The studies in this outcome were downgraded to very low-quality evidence due to risk of bias, inconsistency, and imprecision (Fig. 3a).

\section{PBM plus exercise versus sham plus exercise}

Overall, PBM plus exercise demonstrated significant reductions in pain levels compared to sham plus exercise (MD 1.06; 95\% CI 0.57 to $1.55 ; \mathrm{I}^{2}=82 \% ; n=224$ ). The time period subgroup analysis showed similar results with, PBM plus exercise creating a more substantial decrease in pain at baseline-end of treatment (MD 0.96; $95 \%$ CI 0.27 to $1.64 ; \mathrm{I}^{2}=89 \% ; n=154$ ), and baselinefollow up (MD 1.22; $95 \%$ CI 0.68 to 1.76 ; $\mathrm{I}^{2}=35 \% ; n=$ $70)$. There were no significant between-subgroup differences found $(p=0.55)$. The studies in this outcome were downgraded to low-quality evidence due to inconsistency and Imprecision (Fig. 3b).

\section{PBM plus exercise versus other intervention plus exercise}

No significant difference was found between PBM plus exercise and other interventions (ESWT and US) plus exercise (MD 0.31; $95 \% \mathrm{CI}-0.07$ to $0.70 ; \mathrm{I}^{2}=0 \% ; n=$ 70). The time period subgroup analysis demonstrated similar effects on pain within the baseline-end of 
Table 1 Characteristics of included studies

\begin{tabular}{|c|c|c|c|c|c|c|}
\hline $\begin{array}{l}\text { Study First } \\
\text { Author, } \\
\text { Year }\end{array}$ & Diagnosis & $\begin{array}{l}\text { Total Participants; } \\
\text { Participants per } \\
\text { group }\end{array}$ & Intervention Groups & $\begin{array}{l}\text { Outcomes } \\
\text { Extracted }\end{array}$ & $\begin{array}{l}\text { Treatment } \\
\text { Time }\end{array}$ & Measurement Time Points \\
\hline $\begin{array}{l}\text { Abrisham } \\
2011[42]\end{array}$ & SAS & $80 ; 40 / 40$ & $\begin{array}{l}\text { PBM + Exercise, Sham; Laser + } \\
\text { Exercise }\end{array}$ & VAS & Two weeks & 1. Baseline; 2. Two weeks \\
\hline $\begin{array}{l}\text { Baktir } 2018 \\
{[43]}\end{array}$ & LET & $37 ; 12 / 13 / 13$ & $\begin{array}{l}\text { PBM; Phonophoresis; } \\
\text { Iontophoresis }\end{array}$ & $\begin{array}{l}\text { VAS; PRTEE- } \\
\mathrm{t}\end{array}$ & $\begin{array}{l}\text { Three } \\
\text { weeks }\end{array}$ & 1. Baseline; 2. Two Weeks \\
\hline Bal 2009 [44] & SAS & $44 ; 22 / 22$ & PBM + Exercise; Exercise Only & $\begin{array}{l}\text { VAS; } \\
\text { SPADI-t }\end{array}$ & Two weeks & $\begin{array}{l}\text { 1. Baseline; } 2 \text {. Two weeks; } 3 \text {. Three } \\
\text { month follow up }\end{array}$ \\
\hline $\begin{array}{l}\text { Celik } 2019 \\
{[45]}\end{array}$ & LET & $43 ; 23 / 22$ & PBM + Exercise; ESWT + Exercise & VAS; DASH & Four weeks & $\begin{array}{l}\text { 1. Baseline; } 2 \text {. Four weeks; } 3 \text {. Three } \\
\text { month follow up }\end{array}$ \\
\hline $\begin{array}{l}\text { Devrimsel } \\
2014[46]\end{array}$ & LET & $60 ; 30 / 30$ & PBM; ESWT & VAS & Four weeks & $\begin{array}{l}\text { 1. Baseline; } 2 \text {. Four weeks; } 3 \text {. Three } \\
\text { month follow up }\end{array}$ \\
\hline $\begin{array}{l}\text { Dogan } 2010 \\
{[47]}\end{array}$ & SAS & $52 ; 30 / 22$ & $\begin{array}{l}\text { PBM + Exercise; Sham PBM + } \\
\text { Exercise }\end{array}$ & $\begin{array}{l}\text { VAS; } \\
\text { SAPDI-t }\end{array}$ & $\begin{array}{l}\text { Three } \\
\text { weeks }\end{array}$ & 1. Baseline; 2. Three weeks \\
\hline $\begin{array}{l}\text { Emanet } 2010 \\
{[36]}\end{array}$ & LET & $50 ; 25 / 25$ & $\begin{array}{l}\text { PBM + Exercise; Sham PBM + } \\
\text { Exercise }\end{array}$ & $\begin{array}{l}\text { VAS; DASH; } \\
\text { PRETEE-t }\end{array}$ & $\begin{array}{l}\text { Three } \\
\text { weeks }\end{array}$ & $\begin{array}{l}\text { 1. Baseline; } 2 \text {. Three weeks; } 3 \text {. } \\
\text { Three month follow up }\end{array}$ \\
\hline $\begin{array}{l}\text { Eslamian } \\
2012[37]\end{array}$ & RT & $50 ; 25 / 25$ & $\begin{array}{l}\text { PBM + Passive Physiotherapy; } \\
\text { Sham PBM + Passive } \\
\text { Physiotherapy }\end{array}$ & VAS; SDQ & $\begin{array}{l}\text { Three } \\
\text { weeks }\end{array}$ & $\begin{array}{l}\text { 1. Baseline; } 2 \text {. Four weeks; } 3 \text {. Three } \\
\text { month follow up }\end{array}$ \\
\hline $\begin{array}{l}\text { Kaydok } 2020 \\
{[48]}\end{array}$ & LET & $59 ; 30 / 29$ & $\mathrm{PBM}+\mathrm{HILT}$ & $\begin{array}{l}\text { VAS; QDAS } \\
\mathrm{H}\end{array}$ & $\begin{array}{l}\text { Three } \\
\text { weeks }\end{array}$ & 1. Baseline; 2. Three weeks \\
\hline $\begin{array}{l}\text { Kibar } 2017 \\
{[49]}\end{array}$ & SAS & $62 ; 30 / 32$ & PBM; Sham PBM & $\begin{array}{l}\text { VAS; } \\
\text { SAPDI-t }\end{array}$ & $\begin{array}{l}\text { Three } \\
\text { weeks }\end{array}$ & 1. Baseline; 2. Three weeks \\
\hline $\begin{array}{l}\operatorname{Lam} 2007 \\
{[50]}\end{array}$ & LET & $39 ; 21 / 18$ & $\begin{array}{l}\text { PBM + Exercise; Sham + Exercise } \\
\text { Only }\end{array}$ & VAS; DASH & $\begin{array}{l}\text { Three } \\
\text { weeks }\end{array}$ & 1. Baseline; 2. Three weeks \\
\hline Liu 2014 [38] & PT & $21 ; 7 / 7 / 7$ & $\begin{array}{l}\text { PBM; Exercise Only; PBM + } \\
\text { Exercise }\end{array}$ & VAS; VISA-P & Four Weeks & 1. Baseline; 2. Four weeks \\
\hline $\begin{array}{l}\text { Sharma } 2015 \\
\text { [51] }\end{array}$ & DQT & $30 ; 15 / 15$ & PBM; US & VAS & Two Weeks & 1. Baseline; 2. Two weeks \\
\hline $\begin{array}{l}\text { Stergioulas } \\
2007[52]\end{array}$ & LET & $50 ; 20 / 20$ & PBM + Exercise; Sham + Exercise & VAS & $\begin{array}{l}\text { Four and } \\
\text { Eight } \\
\text { Weeks }\end{array}$ & $\begin{array}{l}\text { 1. Baseline; 2. Eight weeks; 3. Two } \\
\text { month follow up }\end{array}$ \\
\hline $\begin{array}{l}\text { Stergioulas } \\
2008[53]\end{array}$ & AT & $40 ; 20 / 20$ & PBM + Exercise; Sham + Exercise & VAS & $\begin{array}{l}\text { Four and } \\
\text { Eight } \\
\text { Weeks }\end{array}$ & $\begin{array}{l}\text { 1. Baseline; 2. Four weeks; 3. Eight } \\
\text { Weeks; } 4 \text {. Three month follow up }\end{array}$ \\
\hline $\begin{array}{l}\text { Yavuz } 2014 \\
{[54]}\end{array}$ & SAS & $31 ; 16 / 15$ & PBM + Exercise; US + Exercise & $\begin{array}{l}\text { VAS; } \\
\text { SPADI-D }\end{array}$ & Four Weeks & $\begin{array}{l}\text { 1. Baseline; } 2 \text {. Four weeks; } 3 \text {. Three } \\
\text { month follow up }\end{array}$ \\
\hline $\begin{array}{l}\text { Yeldan, } 2009 \\
\text { [55] }\end{array}$ & SAS & $60 ; 34 / 26$ & $\begin{array}{l}\text { PBM + Exercise; Sham PBM + } \\
\text { Exercise }\end{array}$ & $\begin{array}{l}\text { VAS; DASH; } \\
\text { SDQ }\end{array}$ & $\begin{array}{l}\text { Three } \\
\text { Weeks }\end{array}$ & 1. Baseline; 2. Three weeks \\
\hline
\end{tabular}

treatment (MD 0.20; $95 \% \mathrm{CI}-0.34$ to $0.74 ; \mathrm{I}^{2}=0 \% ; n=$ 35 ), and baseline-follow up (MD $0.43 ; 95 \% \mathrm{CI}-0.12$ to $\left.0.97 ; \mathrm{I}^{2}=0 \% ; n=35\right)$ periods. There were no significant between-subgroup differences found $(p=0.57)$. The studies in this outcome were downgraded to moderatequality evidence due to imprecision (Fig. 3c).

\section{Proms}

\section{DASH: PBM plus exercise versus sham plus exercise}

$\mathrm{PBM}$ plus exercise demonstrated a significant improvement in the DASH PROM score compared to sham plus exercise (MD 5.65; 95\% CI 0.25 to $11.04 ; \mathrm{I}^{2}=78 \% n=$ 112). The time period subgroup analysis showed no significant effect of PBM at baseline-end of treatment (MD
2.83; $95 \%$ CI -4.56 to $0.70 ; \mathrm{I}^{2}=80 \% ; n=69$ ), while PBM plus exercise demonstrated a significant positive effect at the baseline-follow up period (MD 9.47; 95\% CI 5.63 to $\left.13.31 ; \mathrm{I}^{2}=0 \% ; n=43\right)$. There were no significant between-subgroup differences found $(p=0.12)$. The studies in this outcome were downgraded to very lowquality evidence due to risk of bias, inconsistency and imprecision (Fig. 4).

\section{Strength measures}

PBM only versus other interventions only

When compared to other interventions only (Phonophoresis, Iontophoresis, ESWT, HILT, CS Injection and US), PBM only, demonstrated a significantly decreased 
Table 2 PBM variables of included studies

\begin{tabular}{|c|c|c|c|c|c|c|}
\hline $\begin{array}{l}\text { Study First } \\
\text { Author, Year }\end{array}$ & $\begin{array}{l}\text { PBM light } \\
\text { source; } \\
\text { Wavelength }\end{array}$ & $\begin{array}{l}\text { Light source power output } \\
\text { during treatment }(\mathrm{mW})\end{array}$ & $\begin{array}{l}\text { Fluence per } \\
\text { spot }\left(\mathrm{J} / \mathrm{cm}^{2}\right)\end{array}$ & $\begin{array}{l}\text { Treatment } \\
\text { spots }\end{array}$ & $\begin{array}{l}\text { PBM sessions per week; } \\
\text { Total PBM sessions }\end{array}$ & $\begin{array}{l}\text { WALT } \\
\text { recommendations } \\
\text { informed trial? }\end{array}$ \\
\hline $\begin{array}{l}\text { Abrisham } \\
2011[42]\end{array}$ & $\begin{array}{l}\text { 'Laser Device;' } \\
890 \mathrm{~nm}\end{array}$ & Not Reported & $2-4$ & 3 & $5 ; 10$ & No \\
\hline $\begin{array}{l}\text { Baktir } 2018 \\
{[43]}\end{array}$ & $\begin{array}{l}\text { GaAs Laser Diode; } \\
904 \mathrm{~nm}\end{array}$ & 0.12 & Not Reported & 5 & $5 ; 15$ & No \\
\hline Bal 2009 [44] & $\begin{array}{l}\text { GaAs Laser Diode; } \\
904 \text { nm }\end{array}$ & 13.2 & 2 & 4 & $5 ; 10$ & No \\
\hline $\begin{array}{l}\text { Celik } 2019 \\
{[45]}\end{array}$ & $\begin{array}{l}\text { GaAs Laser Diode; } \\
904 \mathrm{~nm}\end{array}$ & 40 & 2.4 & 6 & $3 ; 12$ & No \\
\hline $\begin{array}{l}\text { Devrimsel } \\
2014[46]\end{array}$ & 'Laser;' 850 nm & Not Reported & Not Reported & $\begin{array}{l}\text { Not } \\
\text { Reported }\end{array}$ & $2 ; 10$ & No \\
\hline $\begin{array}{l}\text { Dogan } 2010 \\
{[47]}\end{array}$ & GaAlAs; $850 \mathrm{~nm}$ & Not Reported & 5 & $5-6$ & $4-5 ; 14$ & No \\
\hline $\begin{array}{l}\text { Emanet } 2010 \\
\text { [36] }\end{array}$ & $\begin{array}{l}\text { GaAs Laser; } 905 \\
\mathrm{~nm}\end{array}$ & Not Reported & 1 & 2 & $5 ; 15$ & Yes \\
\hline $\begin{array}{l}\text { Eslamian } 2012 \\
\text { [37] }\end{array}$ & $\begin{array}{l}\text { Ga-Al-As Laser } \\
\text { Diode; } 850 \mathrm{~nm}\end{array}$ & 100 & 4 & Up to 10 & $3 ; 9$ & No \\
\hline $\begin{array}{l}\text { Kaydok } 2020 \\
{[48]}\end{array}$ & $\begin{array}{l}\text { Ga-Al-As Laser } \\
\text { Diode; } 904 \text { nm }\end{array}$ & 240 & $2-4$ & 6 & $3 ; 9$ & No \\
\hline $\begin{array}{l}\text { Kibar } 2017 \\
{[49]}\end{array}$ & $\begin{array}{l}\text { Ga-Al-As Laser } \\
\text { Diode; } 850 \mathrm{~nm}\end{array}$ & Not Reported & 4 & 11 & $3 ; 9$ & No \\
\hline Lam 2007 [50] & $\begin{array}{l}\text { Ga-Al-As Laser } \\
\text { Diode; } 904 \text { nm }\end{array}$ & 25 & 2.4 & Average 2.4 & $3 ; 9$ & No \\
\hline Liu 2014 [38] & $\begin{array}{l}\text { Ga-Al-As Laser } \\
\text { Diode; } 810 \mathrm{~nm}\end{array}$ & 200 & Not Reported & 3 & $6 ; 24$ & No \\
\hline $\begin{array}{l}\text { Sharma } 2015 \\
\text { [51] }\end{array}$ & $\begin{array}{l}\text { Ga-Al-As Laser } \\
\text { Diode; } 830 \mathrm{~nm}\end{array}$ & $30-40$ & 3 & $\begin{array}{l}\text { Not } \\
\text { Reported }\end{array}$ & $3-4 ; 7$ & Yes \\
\hline $\begin{array}{l}\text { Stergioulas } \\
2007[52]\end{array}$ & Ga-As; 904 nm & 40 & 2.4 & 6 & $1-2 ; 12$ & No \\
\hline $\begin{array}{l}\text { Stergioulas } \\
2008[53]\end{array}$ & $\begin{array}{l}\text { Ga-Al-As Laser } \\
\text { Diode; } 820 \mathrm{~nm}\end{array}$ & 30 & 0.5 & 6 & $1-2 ; 12$ & Yes \\
\hline $\begin{array}{l}\text { Yavuz } 2014 \\
{[54]}\end{array}$ & $\begin{array}{l}\text { Ga-Al-As Laser } \\
\text { Diode; } 850 \mathrm{~nm}\end{array}$ & Not Reported & 3 & $\begin{array}{l}5 \\
\text { maximum }\end{array}$ & $2-3 ; 10$ & Yes \\
\hline $\begin{array}{l}\text { Yeldan, } 2009 \\
\text { [55] }\end{array}$ & GaAs; 904 nm & Not Reported & Not Reported & 5 Maximum & Not Reported & No \\
\hline
\end{tabular}

effect from baseline-end of treatment (SMD -0.52; 95\% CI -0.81 to $-0.23 ; \mathrm{I}^{2}=0 \% ; n=105$ ) (Fig. $5 \mathrm{a}$ ). The studies in this outcome were downgraded to low-quality evidence due to risk of bias and imprecision.

PBM plus Exercise versus Sham plus Exercise.

Overall, the results demonstrated that PBM plus exercise caused significant increase in strength compared to sham plus exercise (SMD 0.66; 95\% CI 0.11 to $1.21 ; \mathrm{I}^{2}=$ $81 \% ; n=144)$. The time period subgroup analysis however, demonstrated no significant effect for PBM plus exercise on functional strength measures within both the baseline-end of treatment (SMD 0.59; 95\% CI - 0.13 to $-1.31 ; \mathrm{I}^{2}=83 \% ; n=94$ ) and baseline-follow up period (SMD $0.82 ; 95 \% \mathrm{CI}-0.33$ to $1.96 ; \mathrm{I}^{2}=87 \% ; n=50$ ). There were no significant between-subgroup differences found $(p=0.74)$. The studies in this outcome were downgraded to low-quality evidence due to Inconsistency and Imprecision (Fig. 5b).

\section{GRADE classifications}

The quality of evidence classification for each outcome is located in Table 2 in Additional file 1.

\section{Discussion}

The overarching aim of this review was to investigate the effect of low-intensity red and NIR PBM on pain and function in patients with tendinopathy and tendinopathy-related disorders. It was found that when compared to other interventions, with or without exercise added (Phonophoresis, Iontophoresis, ESWT, HILT, CS Injection and US), that there is very low-moderate quality evidence to show that PBM with or without 


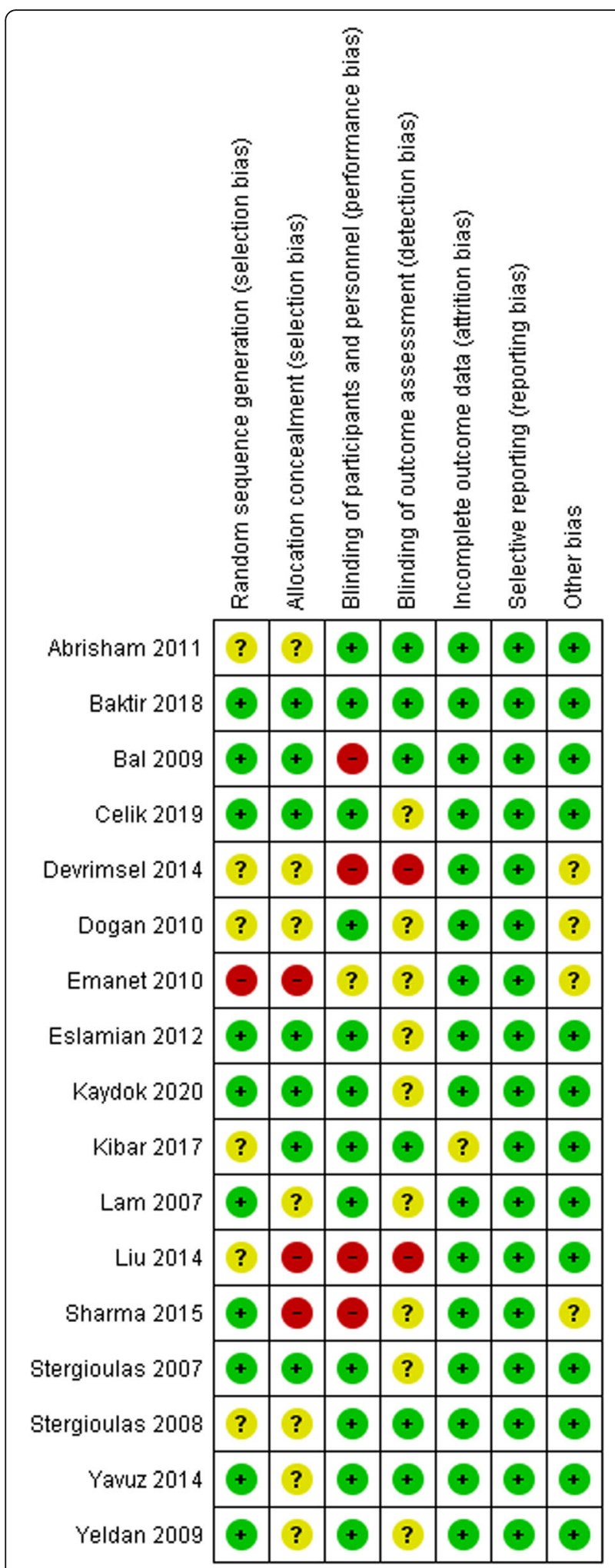

Fig. 2 Risk of bias summary - review authors' judgements about each risk of bias item for each included study exercise were equally effective at reducing pain. This review also found very low-quality evidence demonstrating that when PBM is combined with exercise, it results in a significant improvement in PROMS compared to sham treatment plus exercise. There was also low-quality evidence demonstrating that other interventions (Phonophoresis, Iontophoresis, ESWT, HILT, CS Injection and US) were significantly better at improving functional strength measures compared to PBM, while when exercise was added to PBM therapy, it was significantly better at restoring functional muscle strength compared to sham treatment plus exercise.

Despite the small body of somewhat favorable evidence for PBM, as a whole, there were multiple limitations with the studies included in this review. Firstly, according to the GRADE classification system, all outcome measure assessed were classified as very low, low, or moderate quality of evidence. This was largely due to many of studies been classified as inconsistent $\left(\mathrm{I}^{2}>50 \%\right)$ and imprecise (<400 participants per outcome measure) and judged to be at high risk of bias ( $>25 \%$ trials are classified as high risk). Although the imprecision could be addressed with the inclusion of more studies, the fact that we were not able to assess for publication bias, as no outcomes had more the 10 included trials, is something that will have to be addressed in future trials and reviews. Furthermore, $31.9 \%$ of the risk of bias variables assessed were judged to be of unknown or high-risk of bias, which should be taken into account when interpreting the results of this review.

It is well documented throughout the literature that the inconsistent nature of PBM experiments, both clinical $[41,61]$ and in vitro [14], are a significant hurdle in establishing both a concrete physiological mechanism, and a widely used and accepted set of clinical implementation guidelines. Appraising the studies included in this review, we see many differing forms of PBM application, including total number of treatments, treatment sites, and irradiation per site. This is understandable given they are treating different areas of tendon pathology, however, there were some studies that did not report all the required treatment variables [36, 42, 46, 47, 49, 51, 54 , 55], making exact replication challenging, in the process affecting the quality of evidence. The WALT (World Association for Laser Therapy) recommendations are a set of therapeutic recommendations for clinical and scientific application of red and NIR spectrum PBM [33]. Only four of the trials in this review referenced the WALT recommendations in their study design $[36,51,53,54]$, further underlining the need for higher levels of inter-study consistency.

Heavy strength and plyometric training, in addition to training load management, appear to be the most efficacious exercise modalities to employ during tendinopathy 
a.

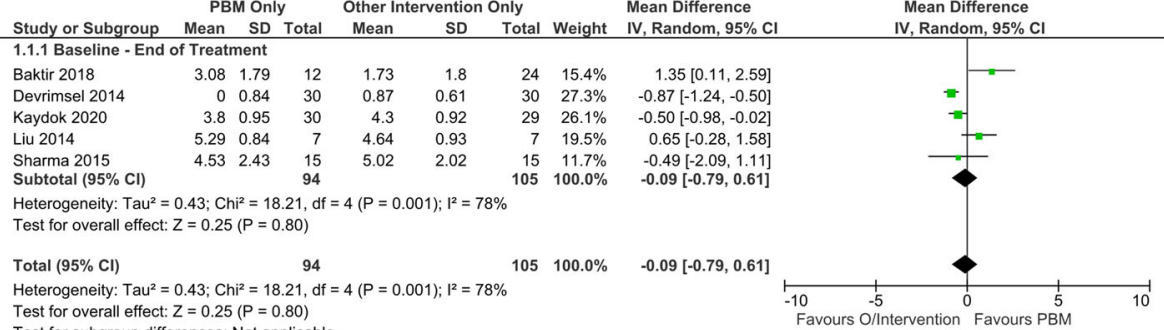

Favours O/Intervention Favours P

Test for subqroup differences: $N$

b.

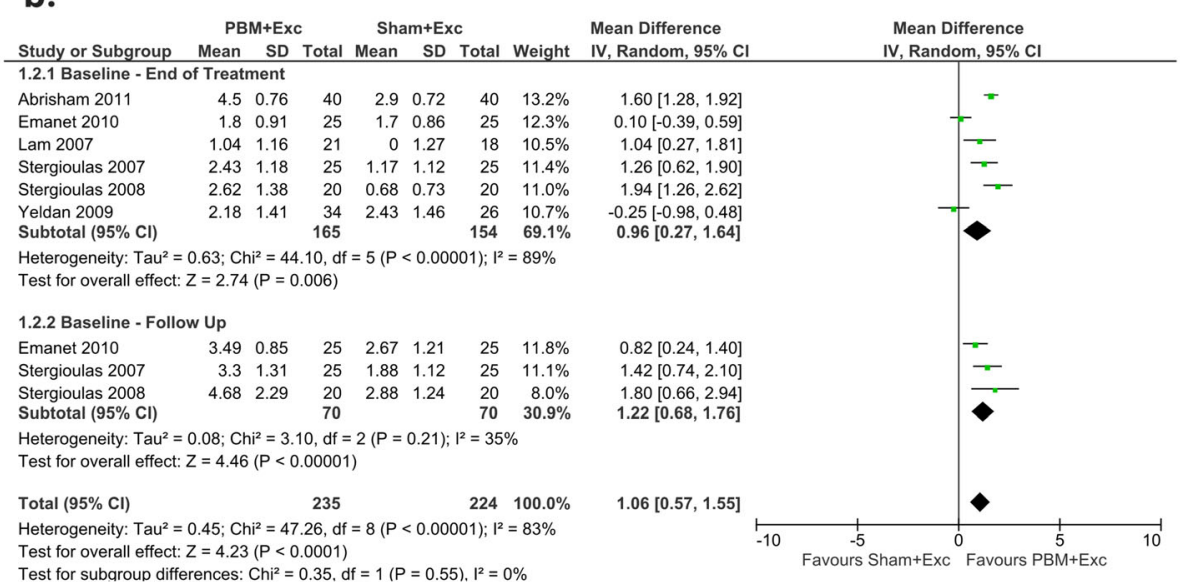

(

C.

PBM+Exc O/Intervention+Exc Mean Difference Mean Difference

Study or Subgroup Mean SD Total Mean SD Total Weight IV, Random, $95 \% \mathrm{Cl} \quad$ IV, Random, $95 \% \mathrm{Cl}$

1.3.1 Baseline - End of Treatment

\begin{tabular}{lrrrrrrrr} 
Celik 2019 & 1.35 & 1.63 & 23 & 1.15 & 1.98 & 20 & $12.3 \%$ & $0.20[-0.89,1.29]$ \\
\hline & 1.7 & 0.86 & 16 & 1.5 & 0.92 & 15 & $37.5 \%$ & $0.20[0.43,0.83]$
\end{tabular} $\begin{array}{llllllllll}\text { Yavuz 2014 } & 1.7 & 0.86 & 16 & 1.5 & 0.92 & 15 & 37.5 \% & 0.20[-0.43,0.83] \\ \text { Subtotal }(95 \% \mathrm{Cl}) & & & 39 & & & 35 & 49.8 \% & 0.20[-0.34,0.74]\end{array}$

Heterogeneity: $\mathrm{Tau}^{2}=0.00 ; \mathrm{Ch}^{2}=0.00, \mathrm{df}=1(P=1.00) ; \mathrm{l}^{2}=0 \%$

Test for overall effect: $Z=0.72(P=0.47)$

1.3.2 Baseline - Follow Up

$\begin{array}{lllllllll}\text { Celik } 2019 & 1.7 & 2.08 & 23 & 1.4 & 1.83 & 20 & 10.8 \% & 0.30[-0.87,1.47]\end{array}$

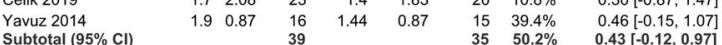
Heterogeneity: $\mathrm{Tau}^{2}=0.00 ; \mathrm{Chi}^{2}=0.06, \mathrm{df}=1(\mathrm{P}=0.81) ; \mathrm{I}^{2}=0 \%$

Test for overall effect: $Z=1.54(P=0.12)$

Total $(95 \% \mathrm{Cl})$

$78 \quad 70 \quad 100.0 \%$

$70 \quad 100.0 \% \quad 0.31[-0.07,0.70]$

Test for overall effect: $Z=1.60(P=0.11$,

Test for subaroup differences: $\mathrm{Chi}^{2}=0.33, \mathrm{df}=1(P=0.57) . \mathrm{I}^{2}=0 \%$ IV, Random,

Fig. 3 VAS: a: Forest plot of comparing PBM only and other interventions (O/Intervention) only; b: Forest plot of the effects of PBM plus exercise (Exc) versus sham treatment plus exercise; c: Forest plot of the effects of PBM plus exercise versus other interventions plus exercise

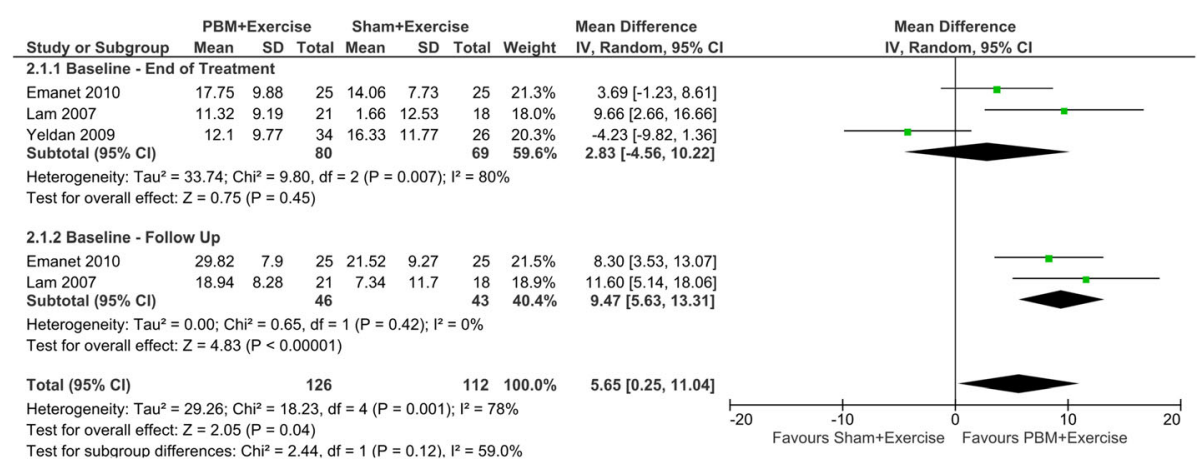

Fig. 4 PROMS: Forest plot of comparing PBM plus exercise versus sham + exercise 
a.

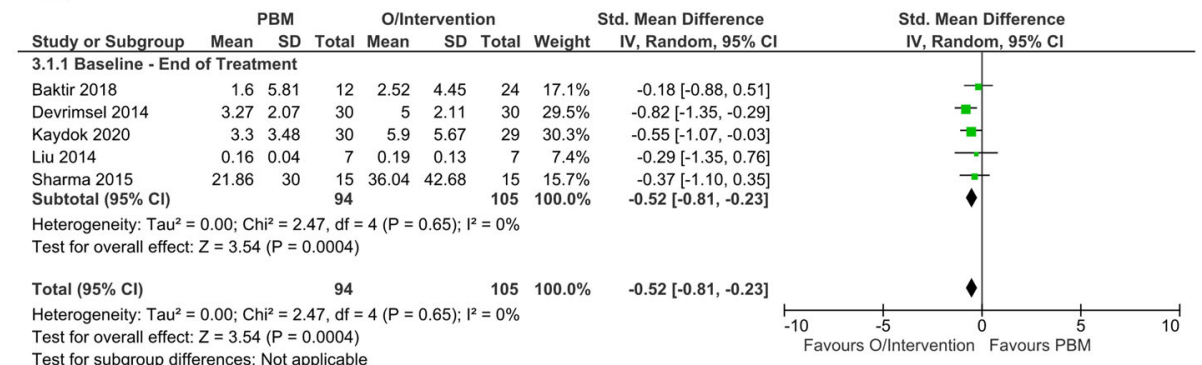

b.

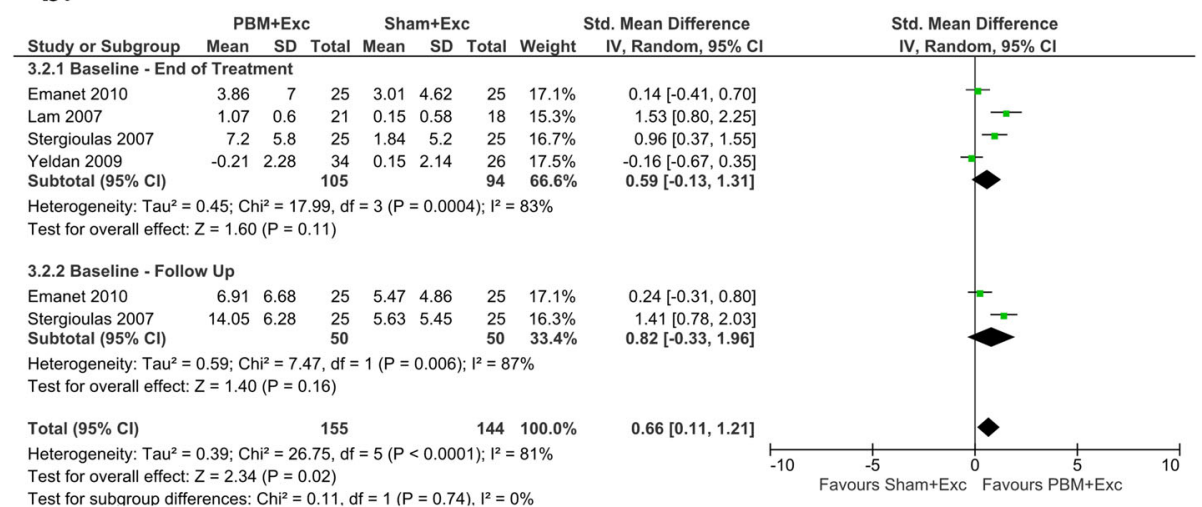

Fig. 5 Strength Measures: a: Forest plot of comparing PBM only and other interventions (O/Intervention) only; $\mathbf{b}$ : Forest plot of the effects of PBM plus exercise (Exc) versus sham treatment plus exercise

management [1]. This review demonstrated very lowquality evidence that PBM could be used as an adjunct therapy to enhance the effects of exercise rehabilitation. That said, a limitation of this analysis was that all the exercise modalities from each study were pooled in each outcome measure, hence different exercise prescriptions may have affected the results. Future research in this area should more stringently control the exercise prescription groups in line with tendinopathy best practice. Interestingly, this review also found that when compared to other interventions, PBM was equally as effective at decreasing pain, however, this was again limited by the pooling of all other interventions. Many of the other interventions that used a pharmacological antiinflammatory agent, such as Phonophoresis, Iontophoresis and CS Injection, can cause unwanted patient side effects [62]. In fact, it is now recommended that practitioners move away from these methods, CS injections in particular, due to the long-term deleterious tissue effects they can have [62]. In light of this, PBM may represent a non-invasive, cost effective and safe alternative to the more traditional injection and anti-inflammatory based therapies used in tendinopathy management. However, more robust trials are needed to elucidate this effect.

To our knowledge only one other systematic review and meta-analysis has been performed on the effect of
PBM on all tendinopathies previously [31]. This review demonstrated similar mixed results concerning the effects of PBM on pain and function in tendinopathy and similar issues with evidence quality to the present review, despite having fewer studies available for analysis. Tendinopathy specific systematic review and metaanalyses have been conducted for shoulder [30] and Achilles tendinopathy [29] and similarly to this review, found a mixed efficacy of PBM underpinned by trials of moderate-very low evidence. Taking these findings together, it is clear that more widespread and robust RCTs are needed to better inform the use of PBM in tendinopathy management.

The strengths of this review include a detailed search of multiple databases, as well as additional searches of paper reference lists. Further, two of the authors performed the entire search process and the risk of bias and GRADE categorization, with a third author resolving any disputes. Another limitation of this study was the fact that all tendinopathies were pooled together as a single diagnostic entity. Hence, the analysis may not have accounted for the heterogeneity of tendinopathy disorders. However, the analysis appeared to indicate similar effects of PBM, regardless of specific diagnosis. More specific-tendinopathy RCTs are needed to underpin more robust single-tendinopathy systematic reviews and 
meta-analyses. Additionally, the exclusion of multiple studies whose required statistics were unobtainable from either the paper, or the contact authors may have changed the study results. As previously stated, the future research focus of PBM for the management of tendinopathy should be set on performing repeated robust RCTs that adequately report and justify all treatment parameters and follow the Consolidated Standard of Reporting Trials (CONSORT) guidelines. This will firstly better elucidate if PBM is an effective standalone and/or adjunct therapy for PBM, and secondly if highquality evidence is found for this effect, it will underpin improved treatment guidelines, potentially translating to improved patient health outcomes.

\section{Conclusion}

$\mathrm{PBM}$ is an increasingly used treatment modality for a range of musculoskeletal disorders, however, there are many questions regarding its mechanisms and true effectiveness that remain under-investigated and unanswered. Currently, there is very-low-to-moderate quality evidence that low-intensity red and NIR PBM is an effective standalone and exercise-adjunctive treatment for tendinopathy disorders in humans. Further, a similar quality of evidence demonstrates that it may have utility as a less-invasive and more risk-averse adjunctive treatment to more traditional passive interventions. More robust RCTs that adhere to the CONSORT guidelines need to be performed to further elucidate its effectiveness.

\footnotetext{
Abbreviations

SAS: Subacromial syndrome; LET: Lateral elbow tendinopathy; RT: Rotator cuff tendinopathy; PT: Patella tendinopathy; AT: Achilles tendinopathy; PBM: Photobiomodulation; ESWT: Extracorporeal shock wave therapy; HILT: High-intensity laser therapy; US: Ultrasound; VAS: Visual analogue scale; DASH: Disabilities of the arm, shoulder and hand measure; QDASH: Quick DASH; PRTEE: Patient reported tennis elbow evaluation; SDQ: Shoulder disability questionnaire; SPADI: Shoulder pain and disability index; VISAP: Victoria institute of sport assessment-patella tendon; WALT: World association for laser therapy; Exc: Exercise; O/Intervention: Other Intervention; MD: Mean Difference; SMD: Standardized mean difference; Cl: Confidence Interval; mW: Milliwatt; J: Joules; NIR: Near-infrared light; RCTs: Randomized controlled trials (RCTs); CCTs: Controlled clinical trials; ATP: Adenosine Triphosphate; NO: Nitric Oxide; CCO: Cytochrome C Oxidase; PROMS: Patient reported outcome measures; PCNA: Proliferating cell nuclear antigen; ROS: Reactive oxygen species
}

\section{Supplementary Information}

The online version contains supplementary material available at https://doi. org/10.1186/s13102-021-00306-z.

Additional file 1: Table 1. Review Search Strategy and Results. Table 2. GRADE Classifications.

\section{Acknowledgments}

The Authors would like to acknowledge the Australian Government for the support of NT and JF through RTP training scholarships. JF was also supported by the the Defence Science Institute and a University of Melbourne PhD Stipend, and NT by a Victoria University PhD Stipend. All authors would like to thank the Immunology and Translational Research Group within the Institute for Health and Sport, Victoria University Australia for their support.

\section{Authors' contributions}

NT was involved in conceptualization, methodology, analysis, writing and project administration. JF was involved in conceptualization, methodology, analysis, and writing. MH was involved in conceptualization, methodology, analysis, and writing. FS was involved in conceptualization, methodology, and writing. VA was involved in conceptualization, methodology, analysis, and writing. All authors read and approved the final manuscript.

\section{Funding}

This research article was supported by the Defence Science Institute, an initiative of the State Government of Victoria, Australia.

\section{Availability of data and materials}

The Pubmed, CINAHL, SCOPUS, Cochrane Database, Web of Science and SPORTSDICUS databases were searched for eligible articles in August 2020'. Additionally, this study was registered with the PROSPERO database (registration number: CRD42020202508). All data and analysis can be made available on request.

\section{Declarations}

Ethics approval and consent to participate

Not applicable.

\section{Consent for publication}

Not applicable.

\section{Competing interests}

The Authors have no competing interests to declare.

\section{Author details}

${ }^{1}$ Institute for Health and Sport, Victoria University, Room 1.16, 301 Flinders Lane, Melbourne, VIC 3000, Australia. ${ }^{2}$ First Year College, Victoria University, Melbourne, Australia. ${ }^{3}$ Australian Institute for Musculoskeletal Science (AIMS S), The University of Melbourne and Western Health, St. Albans, Australia. ${ }^{4}$ Department of Medicine-Western Health, Melbourne Medical School, The University of Melbourne, St. Albans, Australia. ${ }^{5}$ Institute for Sustainable Industries and Liveable Cities, Victoria University, Melbourne, Australia.

Received: 18 February 2021 Accepted: 7 July 2021

Published online: 14 August 2021

\section{References}

1. Cardoso TB, Pizzari T, Kinsella R, Hope D, Cook JL. Current trends in tendinopathy management. Best Pract Res Clin Rheumatol. 2019;33(1):12240. https://doi.org/10.1016/j.berh.2019.02.001.

2. de Jonge S, Van den Berg C, de Vos R-J, Van Der Heide H, Weir A, Verhaar J, et al. Incidence of midportion Achilles tendinopathy in the general population. Br J Sports Med. 2011;45(13):1026-8. https://doi.org/10.1136/ bjsports-2011-090342.

3. Lopes AD, Hespanhol LC, Yeung SS, Costa LOP. What are the main runningrelated musculoskeletal injuries? Sports Med. 2012;42(10):891-905. https:// doi.org/10.1007/BF03262301.

4. Hopkins C, Fu S-C, Chua E, Hu X, Rolf C, Mattila VM, et al. Critical review on the socio-economic impact of tendinopathy. Asia Pacific J Sports Med Arthrosc Rehabil Technol. 2016;4:9-20. https://doi.org/10.1016/j.asmart.2016. 01.002 .

5. Khan KM, Cook JL, Taunton JE, Bonar F. Overuse tendinosis, not tendinitis: part 1: a new paradigm for a difficult clinical problem. Phys Sportsmed. 2000;28(5):38-48. https://doi.org/10.3810/psm.2000.05.890.

6. Khan KM, Cook JL, Kannus P, Maffulli N, Bonar S. Time to abandon the "tendinitis" myth: painful, overuse tendon conditions have a noninflammatory pathology. London: British Medical Journal Publishing Group; 2002

7. Cook J, Purdam CR. Is tendon pathology a continuum? A pathology model to explain the clinical presentation of load-induced tendinopathy. $\mathrm{Br} J$ Sports Med. 2009;43(6):409-16. https://doi.org/10.1136/bjsm.2008.051193. 
8. Scott A, Squier K, Alfredson H, Bahr R, Cook JL, Coombes B, et al. Icon 2019: international scientific tendinopathy symposium consensus: clinical terminology. Br J Sports Med. 2020;54(5):260-2. https://doi.org/10.1136/ bjsports-2019-100885.

9. Cook J. The role of imaging in diagnosing and managing tendinopathy. Ultrasound Med Biol. 2019;45:S16-S7. https://doi.org/10.1016/j.ultra smedbio.2019.07.464.

10. Docking SI, Cook J. Imaging and its role in tendinopathy: current evidence and the need for guidelines. Curr Radiol Rep. 2018;6(11):43. https://doi.org/1 0.1007/s40134-018-0302-8.

11. Mallows A, Debenham J, Walker T, Littlewood C. Association of psychological variables and outcome in tendinopathy: a systematic review. Br J Sports Med. 2017;51(9):743-8. https://doi.org/10.1136/bjsports-2016096154.

12. Silbernagel KG, Vicenzino BT, Rathleff MS, Thorborg K. Isometric exercise for acute pain relief: is it relevant in tendinopathy management? London: BMJ Publishing Group Ltd and British Association of Sport and Exercise Medicine; 2019.

13. Mitham K, Mallows A, Debenham J, Seneviratne G, Malliaras P. Conservative management of acute lower limb tendinopathies: a systematic review. Musculoskelet Care. 2020;19(1):110-26.

14. Tripodi N, Feehan J, Husaric M, Kiatos D, Sidiroglou F, Fraser S, et al. Good, better, best? The effects of polarization on photobiomodulation therapy. J Biophotonics. 2020;13(5):e201960230.

15. Chung H, Dai T, Sharma SK, Huang YY, Carroll JD, Hamblin MR. The nuts and bolts of low-level laser (light) therapy. Ann Biomed Eng. 2012;40(2):51633. https://doi.org/10.1007/s10439-011-0454-7.

16. Lima PL, Pereira CV, Nissanka N, Arguello T, Gavini G, da Costa Maranduba $\mathrm{CM}$, et al. Photobiomodulation enhancement of cell proliferation at $660 \mathrm{~nm}$ does not require cytochrome c oxidase. J Photochem Photobiol B Biol. 2019;194:71-5

17. Hamblin MR. Mechanisms and mitochondrial redox signaling in Photobiomodulation. Photochem Photobiol. 2018;94(2):199-212. https://doi. org/10.1111/php.12864.

18. Feehan J, Tripodi N, Fraser S, Mikkelsen K, Thewlis A, Kiatos D, et al. Polarized light therapy: Shining a light on the mechanism underlying its immunomodulatory effects. J Biophotonics. 2019;13(3):e201960177.

19. Chow R, editor. Is relief of pain with low-level laser therapy (LLLT) a clinical manifestation of laser-induced neural inhibition? Boston: Springer US; 2008.

20. Chen MH, Huang YC, Sun JS, Chao YH, Chen MH. Second messengers mediating the proliferation and collagen synthesis of tenocytes induced by low-level laser irradiation. Lasers Med Sci. 2015;30(1):263-72. https://doi. org/10.1007/s10103-014-1658-5

21. Tsai W-C, Cheng J-W, Chen J-L, Chen C-Y, Chang H-N, Liao Y-H, et al. LoWlevel laser irradiation stimulates tenocyte proliferation in association with increased NO synthesis and upregulation of PCNA and cyclins. Lasers Med Sci. 2014;29(4):1377-84. https://doi.org/10.1007/s10103-014-1528-1.

22. Chen $\mathrm{CH}$, Tsai JL, Wang YH, Lee $\mathrm{CL}$, Chen JK, Huang MH. Low-level laser irradiation promotes cell proliferation and mRNA expression of type I collagen and decorin in porcine achilles tendon fibroblasts in vitro. J Orthop Res. 2009:27(5):646-50. https://doi.org/10.1002/jor.20800.

23. Tsai WC, Hsu CC, Pang JH, Lin MS, Chen YH, Liang FC. Low-level laser irradiation stimulates tenocyte migration with up-regulation of dynamin II expression. PLoS One. 2012;7(5):e38235. https://doi.org/10.1371/journal. pone.0038235.

24. Pires D, Xavier M, Araújo T, Silva JA Jr, Aimbire F, Albertini R. Low-level laser therapy (LLLT; $780 \mathrm{~nm}$ ) acts differently on mRNA expression of anti- and pro-inflammatory mediators in an experimental model of collagenaseinduced tendinitis in rat. Lasers Med Sci. 2011;26(1):85-94. https://doi.org/1 0.1007/s10103-010-0811-z.

25. Torres-Silva R, Lopes-Martins RA, Bjordal JM, Frigo L, Rahouadj R, Arnold G, et al. The low level laser therapy (LLLT) operating in $660 \mathrm{~nm}$ reduce gene expression of inflammatory mediators in the experimental model of collagenase-induced rat tendinitis. Lasers Med Sci. 2015;30(7):1985-90. https://doi.org/10.1007/s10103-014-1676-3.

26. Locke RC, Lemmon EA, Dudzinski E, Kopa SC, Wayne JM, Soulas JM, et al. Photobiomodulation does not influence maturation and mildly improves functional healing of mouse achilles tendons. J Orthop Res. 2020;38(8):1866-75.

27. Pessoa DR, Nicolau RA. Effects of therapy with light emitting diode (LED) in the calcaneal tendon lesions of rats: a literature review. Sci World J. 2019; 2019.
28. Mamais I, Papadopoulos K, Lamnisos D, Stasinopoulos D. Effectiveness of low level laser therapy (LLLT) in the treatment of lateral elbow tendinopathy (LET): an umbrella review. Laser Ther. 2018;27(3):174-86. https://doi.org/10.5978/islsm.27_18-OR-16.

29. Martimbianco ALC, Ferreira RES, Latorraca COC, Bussadori SK, Pacheco RL, Riera R. Photobiomodulation with low-level laser therapy for treating Achilles tendinopathy: a systematic review and meta-analysis. Clin Rehabil. 2020;34(6):713-22. https://doi.org/10.1177/0269215520912820.

30. Haslerud S, Magnussen LH, Joensen J, Lopes-Martins RA, Bjordal JM. The efficacy of low-level laser therapy for shoulder tendinopathy: a systematic review and meta-analysis of randomized controlled trials. Physiother Res Int. 2015;20(2):108-25. https://doi.org/10.1002/pri.1606.

31. Tumilty S, Munn J, McDonough S, Hurley DA, Basford JR, Baxter GD. Low level laser treatment of tendinopathy: a systematic review with metaanalysis. Photomed Laser Surg. 2010;28(1):3-16. https://doi.org/10.1089/ pho.2008.2470.

32. Moher D, Liberati A, Tetzlaff J, Altman DG. Preferred reporting items for systematic reviews and meta-analyses: the PRISMA statement. Ann Intern Med. 2009;151(4):264-9. https://doi.org/10.7326/0003-4819-151-4-2009081 80-00135

33. Bjordal JM. Low level laser therapy (LLLT) and World Association for Laser Therapy (WALT) dosage recommendations. New Rochelle: Mary Ann Liebert, Inc; 2012.

34. Higgins JP, Altman DG, Gøtzsche PC, Jüni P, Moher D, Oxman AD, et al. The Cochrane Collaboration's tool for assessing risk of bias in randomised trials. BMJ. 2011;343:d5928. https://doi.org/10.1136/bmj.d5928.

35. Vicenzino B, de Vos R-J, Alfredson H, Bahr R, Cook JL, Coombes BK, et al. ICON 2019-international scientific tendinopathy symposium consensus: there are nine CORE health-related domains for tendinopathy (CORE DOMAINS): Delphi study of healthcare professionals and patients. $\mathrm{Br} J$ Sports Med. 2020;54(8):444-51. https://doi.org/10.1136/bjsports-2019-1 00894.

36. Emanet SK, Altan LI, Yurtkuran M. Investigation of the effect of GaAs laser therapy on lateral epicondylitis. Photomed Laser Surg. 2010;28(3):397-403. https://doi.org/10.1089/pho.2009.2555.

37. Eslamian F, Shakouri SK, Ghojazadeh M, Nobari OE, Eftekharsadat B. Effects of low-level laser therapy in combination with physiotherapy in the management of rotator cuff tendinitis. Lasers Med Sci. 2012;27(5):951-8. https://doi.org/10.1007/s10103-011-1001-3.

38. Liu X-G, Cheng L, Song J-M. Effects of low-level laser therapy and eccentric exercises in the treatment of patellar tendinopathy. Int J Photoenergy. 2014 2014:1-6. https://doi.org/10.1155/2014/785386.

39. Higgins JPT, Thomas J, Chandler J, Cumpston M, Li T PM, Welch VA, et al. Cochrane handbook for systematic reviews of interventions Cochrane; 2020. Available from: www.training.cochrane.org/handbook.

40. Schünemann $H$, Brożek J, Guyatt G, Oxman A, editors. GRADE handbook for grading quality of evidence and strength of recommendations: The GRADE Working Group; 2013. Available from: guidelinedevelopment.org/handbook

41. Tomazoni SS, Almeida MO, Bjordal JM, Stausholm MB, Machado CSM, LealJunior ECP, et al. Photobiomodulation therapy does not decrease pain and disability in people with non-specific low back pain: a systematic review. J Phys. 2020;66(3):155-65.

42. Abrisham SM, Kermani-Alghoraishi M, Ghahramani R, Jabbari L, Jomeh $\mathrm{H}$, Zare M. Additive effects of low-level laser therapy with exercise on subacromial syndrome: a randomised, double-blind, controlled trial. Clin Rheumatol. 2011;30(10):1341-6. https://doi.org/10.1007/s10067-011-1757-7.

43. Baktir S, Razak Ozdincler A, Kaya Mutlu E, Bilsel K. The short-term effectiveness of low-level laser, phonophoresis, and iontophoresis in patients with lateral epicondylosis. J Hand Ther. 2019;32(4):417-25. https:// doi.org/10.1016/j.jht.2018.01.002.

44. Bal A, Eksioglu E, Gurcay E, Gulec B, Karaahmet O, Cakci A. Low-level laser therapy in subacromial impingement syndrome. Photomed Laser Surg. 2009;27(1):31-6. https://doi.org/10.1089/pho.2007.2222.

45. Celik D, Anaforoglu KB. Photobiomodulation therapy versus extracorporeal shock wave therapy in the treatment of lateral epicondylitis. Photobiomodul Photomed Laser Surg. 2019;37(5):269-75. https://doi.org/1 0.1089/photob.2018.4533.

46. Devrimsel G, Kucukali Turkyilmaz A, Yildirim M, Ulasli MA. A comparison of laser and extracorporeal shock wave therapies in treatment of lateral epicondylitis. Turkiye Fiziksel Tip Rehabil Dergisi. 2014;60(3):194-8. https:// doi.org/10.5152/tftrd.2014.31643. 
47. Dogan SK, Ay S, Evcik D. The effectiveness of low laser therapy in subacromial impingement syndrome: a randomized placebo controlled double-blind prospective study. Clinics (Sao Paulo). 2010;65(10):1019-22. https://doi.org/10.1590/S1807-59322010001000016.

48. Kaydok E, Ordahan B, Solum S, Karahan AY. Short-term efficacy comparison of high-intensity and low-intensity laser therapy in the treatment of lateral epicondylitis: a randomized double-blind clinical study. Arch Rheumatol. 2020;35(1):60-7. https://doi.org/10.5606/ArchRheumatol.2020.7347.

49. Kibar S, Konak HE, Evcik D, Ay S. Laser acupuncture treatment improves pain and functional status in patients with subacromial impingement syndrome: a randomized, double-blind, Sham-Controlled Study. Pain Med. 2017;18(5): 980-7. https://doi.org/10.1093/pm/pnw197.

50. Lam LK, Cheing GL. Effects of 904-nm low-level laser therapy in the management of lateral epicondylitis: a randomized controlled trial. Photomed Laser Surg. 2007;25(2):65-71. https://doi.org/10.1089/pho.2006.2 047.

51. Sharma R, Aggarwal AN, Bhatt S, Kumar S, Bhargava SK. Outcome of low level lasers versus ultrasonic therapy in de Quervain's tenosynovitis. Indian J Orthop. 2015;49(5):542-8. https://doi.org/10.4103/0019-5413.164050.

52. Stergioulas A. Effects of low-level laser and plyometric exercises in the treatment of lateral epicondylitis. Photomed Laser Surg. 2007;25(3):205-13. https://doi.org/10.1089/pho.2007.2041.

53. Stergioulas A, Stergioula M, Aarskog R, Lopes-Martins RA, Bjordal JM. Effects of low-level laser therapy and eccentric exercises in the treatment of recreational athletes with chronic achilles tendinopathy. Am J Sports Med. 2008:36(5):881-7. https://doi.org/10.1177/0363546507312165.

54. Yavuz F, Duman I, Taskaynatan MA, Tan AK. Low-level laser therapy versus ultrasound therapy in the treatment of subacromial impingement syndrome: a randomized clinical trial. J Back Musculoskelet Rehabil. 2014; 27(3):315-20. https://doi.org/10.3233/BMR-130450.

55. Yeldan I, Cetin E, Ozdincler AR. The effectiveness of low-level laser therapy on shoulder function in subacromial impingement syndrome. Disabil Rehabil. 2009:31(11):935-40. https://doi.org/10.1080/09638280802377985.

56. Alizadeh A, Mardani-Kivi M, Ebrahimzadeh MH, Rouhani A, Hashemi K, Saheb-Ekhtiari K. A randomized prospective comparative study of four methods of biceps tendonitis treatment: ultrasound, low-level laser + ultrasound, intra-sheath, and extra-sheath corticosteroid guided injection. Shiraz e Med J. 2018;19(11) no pagination.

57. Güloğlu SB. Comparison of low-level laser treatment and extracorporeal shock wave therapy in subacromial impingement syndrome: a randomized, prospective clinical study. Lasers in Medical Science. 2021;36(4);773-81

58. Otadi K, Hadian MR, Olyaei G, Jalaie $\mathrm{S}$. The beneficial effects of adding low level laser to ultrasound and exercise in Iranian women with shoulder tendonitis: a randomized clinical trial. J Back Musculoskelet Rehabil. 2012; 25(1):13-9. https://doi.org/10.3233/BMR-2012-0305.

59. Skorupska E, Lisinski P, Samborski W. The effectiveness of the conservative versus myofascial pain physiotherapy in tennis elbow patients: double-blind randomized trial of 80 patients. J Musculoskelet Pain. 2012;20(1):41-50. https://doi.org/10.3109/10582452.2011.635846.

60. Tumilty S, McDonough S, Hurley DA, Baxter GD. Clinical effectiveness of low-level laser therapy as an adjunct to eccentric exercise for the treatment of Achilles' tendinopathy: a randomized controlled trial. Arch Phys Med Rehabil. 2012;93(5):733-9. https://doi.org/10.1016/j.apmr.2011.08.049.

61. Stausholm MB, Naterstad IF, Joensen J, Lopes-Martins RÁB, Sæbø H, Lund H, et al. Efficacy of low-level laser therapy on pain and disability in knee osteoarthritis: systematic review and meta-analysis of randomised placebocontrolled trials. BMJ Open. 2019;9(10):e031142.

62. Dean BJF, Lostis E, Oakley T, Rombach I, Morrey ME, Carr AJ. The risks and benefits of glucocorticoid treatment for tendinopathy: a systematic review of the effects of local glucocorticoid on tendon. Semin Arthritis Rheum. 2014;43(4):570-6. Elsevier.

\section{Publisher's Note}

Springer Nature remains neutral with regard to jurisdictional claims in published maps and institutional affiliations.

Ready to submit your research? Choose BMC and benefit from:

- fast, convenient online submission

- thorough peer review by experienced researchers in your field

- rapid publication on acceptance

- support for research data, including large and complex data types

- gold Open Access which fosters wider collaboration and increased citations

- maximum visibility for your research: over $100 \mathrm{M}$ website views per year

At BMC, research is always in progress.

Learn more biomedcentral.com/submissions 